九州大学学術情報リポジトリ

Kyushu University Institutional Repository

\title{
An Assessment of the Role of Sebesi Island as a Stepping-stone for the Colonisation of the Klakatau Islands by Butterflies
}

Yukawa, Junichi

Partomihardjo, Tukirin

Yata, 0samu

Hirowatari, Toshiya

https://doi.org/10.5109/2638

出版情報: ESAKIA. 40，pp.1-10，2000-03-31. Entomological Laboratory，Faculty of Agriculture， Kyushu University

バージョン :

権利関係 : 


\title{
An Assessment of the Role of Sebesi Island as a Stepping-stone for the Colonisation of the Krakatau Islands by Butterflies ${ }^{1)}$
}

\author{
Junichi YUKAWA ${ }^{2)}$ \\ Entomological Laboratory, Faculty of Agriculture, \\ Kyushu University, Fukuoka, 812-8581 Japan \\ Tukirin PARTOMihardjo \\ Herbarium Bogoriense, Botanical Division, Center for R \& D in Biology, \\ Indonesian Institute of Sciences, Bogor, 16122 Indonesia

\section{Osamu YATA} \\ Biosystematics Laboratory, Graduate School of Social and Cultural \\ Studies, Kyushu University, Fukuoka, 810-8560 Japan \\ and

\section{Toshiya HirowataRI} \\ Entomological Laboratory, College of Agriculture, Osaka Prefecture \\ University, Sakai, Osaka, 599-8531 Japan
}

\begin{abstract}
Thirty-three butterfly species were collected in July 1993 from Sebesi and Sebuku Islands, Indonesia. Most of them were identified at the subspecies level, except several lycaenids. Fourteen species $(42.4 \%)$ out of the 33 have never been recorded from the Krakataus. This proportion is distinctly higher than 4 to 8 (13.3 to $26.7 \%$ ) of 30 species recorded from Sebesi in 1989. When these data were taken together, the percentage becomes 32.7 to $40.4 \%$ (17 to 21 of 52 species recorded from Sebesi-Sebuku). Comparison between Javanese and Sumatran subspecies in the rate of common species on Sebesi-Sebuku and the Krakataus indicates that the butterfly fauna of the Krakataus have been chiefly derived from Java rather than from Sumatra even though the 2 stepping-stone islands exist between the Krakataus and Sumatra.

Key words: Krakatau Islands, Sebesi Island, butterfly, derivation of fauna, colonisation, stepping-stone.
\end{abstract}

1) Contribution from the Entomological Laboratory, Faculty of Agriculture, Kyushu University, Fukuoka (Ser.5, No.42).

2) To whom all correspondence should be addressed at: Fax: +81-92-642-2837, Email: jyukawa@agr.kyushu-u.ac.jp 


\section{Introduction}

The Krakatau Islands are situated in the Sunda Strait, Indonesia, about $40 \mathrm{~km}$ away from the coast of Java and $35 \mathrm{~km}$ from Sumatra and now consist of 4 islands, Rakata, Panjang, Sertung, and Anak Krakatau (Fig. 1). As is well known, the first 3 islands were effectively sterilized by the 1883 catastrophic eruption of Krakatau Island, of which Rakata is the remnant. Anak Krakatau appeared above the sea in the 1930s as a result of submarine volcanic activity. Since the eruption, special attention has been paid to the ecological succession on the Krakatau Islands and various faunistic and floristic data have been accumulated (see Thornton, 1996a for literature).

There have been 2 opinions as to the derivation of fauna on the Krakataus (e.g., Dammerman, 1948; Thornton, 1996a, 1996b; Yukawa, 1984). One is that the fauna has been derived chiefly from Sumatra via 2 stepping-stone islands, Sebesi and Sebuku. Another is that it has been derived mainly from Java. The latter opinion has been supported by the relative abundance of Javanese forms over Sumatran ones in the insect groups of aculeata Hymenoptera (Sk.Yamane, 1983), butterflies (Yukawa, 1984), and termites (Sk.Yamane et al., 1992).

Thus, the provision of data indicating the proportions of species deriving from Sumatra and from Java is an appropriate way of contributing to the aforementioned discussion. However, further entomofaunal data are still required, particularly from Sebesi and Sebuku Islands, which are much less well known entomologically than the Krakataus in spite of several previous surveys (e.g., Dammerman, 1922, 1948; Docters van Leeuwen, 1923; Bush et al., 1990) and the role of Sebesi and Sebuku Islands as stepping-stones for the colonisation of the Krakatau Islands by various insect groups needs to be assessed more precisely.

In order to calculate the relative abundance of species of Sumatran and Javanese origin and the ratio of species that occur both on the Krakataus and on Sebesi and Sebuku, insects must be identified at the subspecies level and distributional information on the species concerned is required. Butterflies are suitable for such a faunistic survey since they can be more easily identified, frequently at the subspecies level, than other insect groups. Their host plants and distributional range are also relatively well known. In addition, the butterfly fauna of the Krakataus has been surveyed intensively on many occasions, particularly during the period from 1982 to 1999 (Yukawa, 1984; Bush, 1986; New et al., 1988; Bush et al., 1990; Bush \& Whittaker, 1991; New \& Thornton, 1992). In the light of these considerations, the butterfly fauna of Sebesi and Sebuku Islands was surveyed in 1993 in order to assess the role of these islands as stepping-stones for the colonisation of the Krakatau Islands by butterflies.

\section{Materials and Methods}

Sebesi Island is almost circular, with a diameter of from 6 to $8 \mathrm{~km}$. The summit is 844 $\mathrm{m}$ high. The island is about $16 \mathrm{~km}$ from the nearest coasts of both Krakatau and Sumatra (Fig. 1). It has been extensively deforested and converted to coconut and banana plantations since the 1970s. Sebuku is a low island with about the same area as Sebesi and is about $2.5 \mathrm{~km}$ north of Sebesi and about $2.3 \mathrm{~km}$ south of Sumatra. The native forest of Sebuku has been largely eradicated. 


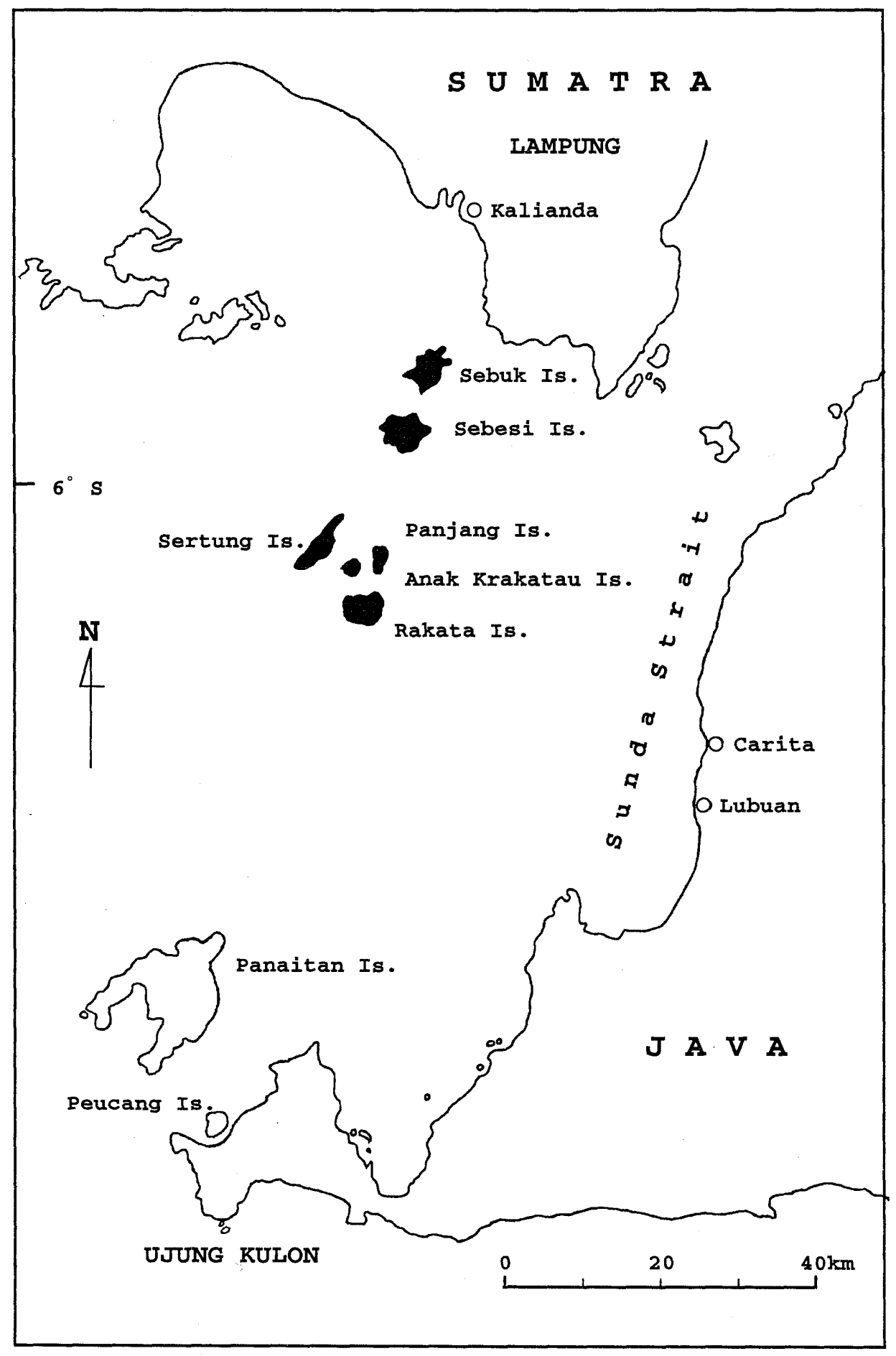

Fig. 1. Map of the Krakatau Islands and surroundings. 
Butterflies were netted randomly by Junichi Yukawa and Tukirin Partomihardjo on Sebesi for fully 1 day on 11 July 1993 and on Sebuku for half day on 12 July 1993. On Sebesi the collection was undertaken in villages, around beach vegetation, and along field boundaries, not in the high uplands. Since the collection on Sebuku was restricted to beach vegetation owing to the limited time of stay, the role of Sebuku as a stepping-stone could not be assessed independently. Therefore the collection data from Sebesi and Sebuku are taken together in the following assessment.

The butterflies were identified by Osamu Yata and Toshiya Hirowatari to the subspecies level, as many species as possible to the subspecies level. The identified subspecies were divided into 3 categories: Javanese, Sumatran, and widely distributed, of which the last category includes species distributed both in Java and in Sumatra.

Further distributional information on the butterfly taxa was obtained from Evans (1949), Corbet \& Pendlebury (1978), Tsukada (1980-1991), Otsuka (1988, 1991), Yata (1995). Records of butterflies from the Krakataus in the 1980s-1990s were taken from Yukawa (1984), Bush \& Whittaker (1991), and New \& Thornton (1992). Records of butterflies known in recent years on Sebesi and Sebuku were obtained from Bush et al. (1990).

\section{Results}

\section{Butterflies on Sebesi-Sebuku and the Krakatau Islands}

In 1993, 29 and 16 butterfly species were collected from Sebesi and Sebuku, respectively (Table 1), totalling 33 species in 26 genera belonging to 5 families. Prior to the 1993 survey, 30 butterfly species, including 4 unidentified and 1 temporarily identified species were collected from Sebesi in 1989 (Bush et al., 1990) (Table 2). Of these 11 were found also in 1993. As a result, butterflies recorded from Sebesi-Sebuku in 1989-1993 totalled 52 species.

On the Krakatau Islands, 92 butterfly species, including 5 unidentified and 3 temporarily identified species, were recorded during the period from 1984 to 1992 (Yukawa, 1984; Bush \& Whittaker, 1991; New \& Thornton, 1992) (Table 2).

\section{Common species on Sebesi-Sebuku and the Krakataus}

Fourteen species (42.4\%) out of the 33 that were collected in 1993 on Sebesi-Sebuku have never been recorded from the Krakataus (Table 2). This proportion is distinctly higher than $4(13.3 \%$; 4 unidentified species were excluded) or $8(26.7 \%)$ of the 30 species that had been collected in 1989 from Sebesi (Table 1). When the 1989 and 1993 data were taken together, 17 to 21 (32.7 to $40.4 \%$ ) of 52 species that had been recorded from Sebesi-Sebuku in 1989-1993 were not known on the Krakataus.

\section{Distribution of subspecies}

Among 33 species that were collected in 1993 on Sebesi-Sebuku, 5 lycaenids could not be identified at the subspecies level, but the remaining 28 were classified into subspecies and the distributional range of each subspecies was obtained from the literature (Table 1). In order to determine the source area from which these subspecies came to SebesiSebuku, they were divided, based on their distributional range, into 3 categories: Javanese, Sumatran, and Wide (Table 1). The Javanese category comprises species with 
Table 1. Butterflies collected in 1993 from Sebesi and Sebuku Islands, and category of each species based on distributional information.

\begin{tabular}{|c|c|c|c|}
\hline & Sebesi & Sebuku & Category based on distribution range ${ }^{1)}$ \\
\hline \multicolumn{4}{|l|}{ Papilionidae } \\
\hline Graphium agamemnon agamemnon (Linnaeus, 1758) & $1 \delta^{\pi}$ & -- & W: N.India-Indo China-Sundaland \\
\hline Papilio memnon memnon Linnaeus, 1758 & $2 \sigma^{\pi}$ & -- & J: Borneo, Java, Bali \\
\hline Papilio polytes javanus C.Felder, 1862 & 10 & -- & $\mathrm{J}:$ Java \\
\hline \multicolumn{4}{|l|}{ Pleriane } \\
\hline Appias Iyncida hippo (Cramer, 1779) & -- & $1 \sigma^{\pi}$ & S: W.Sumatra \\
\hline Catopsilia pyranthe pyranthe (Linnaeus, 1758) & 1 우 & - & W: India-Indo China-Sundaland-Sulawesi \\
\hline Eurema blanda blanda (Boisduval, 1836) & $3 ð$ & 1 우 & W: Malay Pen., Sumatra, Borneo, Java \\
\hline Eurema hecabe hecabe (Linnaeus, 1758) & $2 \precsim$ & 1 우 & W: China-Indo China-Sundaland \\
\hline \multicolumn{4}{|l|}{ Lycaentare } \\
\hline Flos apidanus (Cramer, 1777) & 1 우 & -- & ?: Subspecific identification impossible ${ }^{2)}$ \\
\hline Hypolycaena erylus (Godart, 1824) & $1 \sigma^{\pi}$ & -- & ?: Subspecific identification impossible $e^{3)}$ \\
\hline Jamides aratus (Stoll, 1781) & 1 우 & -- & ?: Subspecific identification impossible ${ }^{4)}$ \\
\hline Jamides celeno (Cramer, 1775) & 6万ำ우 & $10^{\pi}$ & ?: India-New Guinea, Solomons ${ }^{5)}$ \\
\hline Miletus symethus (Cramer, 1779) & 2 우 & -- & ?: Subspecific identification impossible $e^{6)}$ \\
\hline zizula hylax (Fabricius, 1795) & $5 \sigma^{\lambda} 1$ 우 & $10^{\pi}$ & W: old world tropics \\
\hline
\end{tabular}

\section{Nymphalidae (Danainae)}

Ideopsis juventa robinsoni (Rothschild, 1920) $2 \delta^{\Uparrow} 2$ 우 -- $\quad$ S: W. \& S.Sumatra

\section{Nymphalidae (Nymphalinae)}

Ariadne ariadne pallidior Fruhstorfer, 1899

Chersonesia rahria rahria (Moore, 1857)

Cupha erymanthis erymanthis (Drury, 1773)

Hypolimas bolina bolina (Jinnaeus, 1758)

Junonia atlites atlites (Linnaeus, 1758)

Junonia iphita horsfieldi (Moore, 1899)

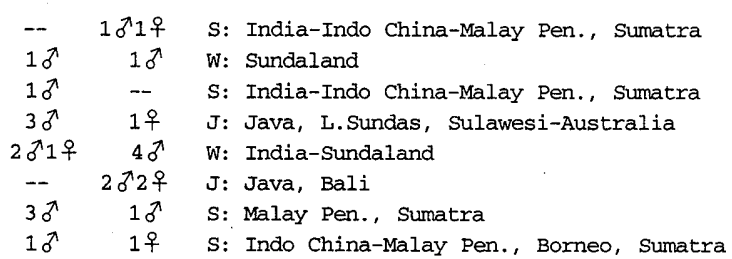

Neptis hylas papaja Moore, 1874

Neptis ilira cindia Eliot, 1969

s: Indo China-Malay Pen., Borneo, Sumatra

\section{Nymphalface (Satyrinae)}

Amathusia phidippus phidippus (Linnaeus, 1763) $1 \delta$-- W: Indo China-Sundaland

Elymnias nesaea nesaea (Linnaeus, 1758) -- $1 \sigma^{\pi} \mathrm{J}$ : W.Java

Melanithis leda lacrima Frubstorfer, $1908 \quad 2 \delta_{1}$ 우 -- J: Java, Bali, L.Sundas

Mycalesis mineus micromalayana Fruhstorfer, 1911 1우 $1 \delta^{\natural} 2$ 우 $\mathrm{W}$ : Sundaland

Orsoyriaena medus medus (Fabricius, 1775) $2 \delta^{\lambda} 4$ 우 1 우 W: Indo China-Sundaland-New Guinea

Ypthima baldus moerus Fruhstorfer, $1911 \quad 1 \delta \quad 1 ð \quad \mathrm{~S}$ : Sumatra

Ypthima philomela philomera (Linnaeus, 1763) $6 \sigma^{\Uparrow} \quad-$ W: Sumatra, Java, Bali

\section{Hesperildae}

Parnara apostata apostata (Snellen, 1886) -- S: C.Sumatra

Parnara naso bada (Moore, 1878) $1 \sigma^{\pi}--$ W: Oriental Region

Pelopidas mathias mathias (Fabricius, 1798) 2 우 -- W: Oriental Region

Taractrocera ziclea tissara Fruhstorfer, $1910 \quad 2$ 구 $\quad$-.. $\quad$ S: Sumatra

1) J: Javanese category; distribution range including Java, but not Sumatra.

S: Sumatran category; distribution range including Sumatra, but not Java.

W: Wide distribution category; distribution range including both Java and Sumatra.

?: Distribution range unknown since butterflies were not identified to the subspecies level.

2) ssp. apidanus (Java), ssp. saturatus (Malay Pen., Borneo, Sumatra).

3) ssp. erylus (Java), spp. teatus (Malay Pen., Borneo, Sumatra).

4) ssp. tryphiodorus (Java), spp. adana (Malay Pen., Borneo, Sumatra).

5) ssp. celeno (Sumatra), spp. ruvana (Java, Bali, Lombok).

6) ssp. symethus (E. Java), spp. nuctus (C. \& S. Sumatra). 


\section{J. YUKAWA, T. PARTOMIHARDJO, O. YATA \& T. HIROWATARI}

Table 2. A list of butterfly species recorded from the Krakataus in 1984-1992, from Sebesi in 1989, and from Sebesi-Sebuk in 1993.

\begin{tabular}{|c|c|c|c|c|}
\hline Family & Species & $\begin{array}{l}\text { Krakataus } \\
1984-1992 \\
\end{array}$ & $\begin{array}{c}\text { Sebesi } \\
1989\end{array}$ & $\begin{array}{c}\text { Sebesi-Sebuku } \\
1993 \\
\end{array}$ \\
\hline \multirow[t]{11}{*}{ PAPILIONIDAE } & Graphium agamemnon agamemnon (Linnaeus) & + & + & + \\
\hline & Graphium doson evemonides (Honrath) & + & - & - \\
\hline & Graphium sarpedon (Linnaeus) & + & - & - \\
\hline & Pachliopta aristolochiae adamas (zinken) & + & - & - \\
\hline & $\begin{array}{l}\text { Pachliopta aristolochiae antiphus } \\
\text { (Fabricius) }\end{array}$ & + & - & - \\
\hline & Papilio helenus engarius Doherty & + & - & - \\
\hline & Papilio peranthus Fabricius & + & - & - \\
\hline & Papilio polytes javanus C. Felder & - & - & + \\
\hline & Papilio memnon memnon Linnaeus & $+^{1)}$ & $+1)$ & + \\
\hline & Troides helena helena (Linnaeus) & + & + & - \\
\hline & Subtotal & $8^{27}$ & 3 & 3 \\
\hline \multirow[t]{15}{*}{ PIERIDAE } & Appias indra leptis (C. \& R. Felder) & + & - & - \\
\hline & Appias lyncida hippo (Cramer) & - & - & + \\
\hline & Appias Iyncida Iyncida (Cramer) & + & - & - \\
\hline & Appias nero nero (Fabricius) & + & - & - \\
\hline & Appias paulina leis (Hübner) & + & - & - \\
\hline & Belenois java java (Sparrman) ${ }^{3}$ & + & - & - \\
\hline & Catopsilia pomona pomona (Fabricius) & + & - & - \\
\hline & Catopsilia pyranthe pyranthe (Linnaeus) & - & - & + \\
\hline & Cepora iudith iudith (Fabricius) & + & - & - \\
\hline & Eurema alitha sankapura (Fruhstorfer) & + & - & - \\
\hline & Eurema blanda blanda (Boisduval) & + & + & + \\
\hline & Eurema hecabe hecabe (Linnaeus) & + & + & + \\
\hline & Gandaca harina harina (Horsfield) & + & - & - \\
\hline & Pareronia valeria leona (Fruhstorfer) & + & - & - \\
\hline & $\begin{array}{l}\text { Subtotal } \\
\end{array}$ & 12 & 2 & 4 \\
\hline \multirow{37}{*}{$\begin{array}{l}\text { D } \\
\\
\end{array}$} & Allotinus felderi Semper & + & - & - \\
\hline & Allotinus unicolor Felder & + & - & - \\
\hline & Anthene emolus Godart & + & - & - \\
\hline & $\begin{array}{l}\text { Arhopala pseudocentaurus } \\
\text { pseudocentaurus (Doubleday) }\end{array}$ & + & + & - \\
\hline & Arhopala sp. & - & + & - \\
\hline & Catochrysops panormus (C. Felder) & + & + & - \\
\hline & Catochrysops strabo (Fabricius) & + & + & - \\
\hline & Catopylops ancyra (C. Felder) & + & - & - \\
\hline & Deudorix jarbas dekaiarchus Fruhstorfer & + & - & - \\
\hline & Euchrysops cnejus cnejus (Fabricius) & + & + & - \\
\hline & Everes lacturnus Godfrey & - & + & - \\
\hline & Flos apidanus (Cramer) & - & - & + \\
\hline & Hypolycaena erylus erylus (Godart) & + & - & $+1)$ \\
\hline & Hypolycaena ithna Hewitson & + & - & - \\
\hline & Jamides aratus (Stoll) & + & - & + \\
\hline & Jamides bochus (Stoll) & + & + & - \\
\hline & Jamides celeno celeno (Cramer) & $+1)$ & $+1 "$ & + \\
\hline & Jamides elpis (Godart) & + & - & - \\
\hline & Jamides malaccanus (Röber) & + & - & - \\
\hline & Jamides pura Moore & + & - & - \\
\hline & Lampides boeticus (Linnaeus) & + & + & - \\
\hline & Loxura atymnus (Stoli) & + & - & - \\
\hline & Megisba malaya malaya (Horsfield) & + & - & - \\
\hline & Miletus boisduvalii Moore & + & - & - \\
\hline & Miletus symethus (Cramer) & + & - & + \\
\hline & Miletus sp. & + & - & - \\
\hline & Nacaduva beroe Felder & + & - & - \\
\hline & ?Nacaduba pactolus (C. Felder) & + & - & - \\
\hline & Petrelaea dana dana (de Nicéville) & + & - & - \\
\hline & Prosotas dubiosa(Semper) & + & + & - \\
\hline & Prosotas lutea (Martin) & + & - & - \\
\hline & Rapala iarbus Fruhstorfer & + & - & 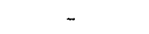 \\
\hline & Spalgis epius Westwood & + & - & - \\
\hline & Zizeeria karsandra Moore & - & + & - \\
\hline & zizina otis Iysizone (Snellen) & + & + & - \\
\hline & zizula hylax (Fabricius) & + & - & + \\
\hline & Subtotal & 32 & 12 & 6 \\
\hline
\end{tabular}


Table 2. A list of butterfly species recorded from the Krakataus in 1984-1992, from Sebesi in 1989, and from Sebesi-Sebuk in 1993. (continued)

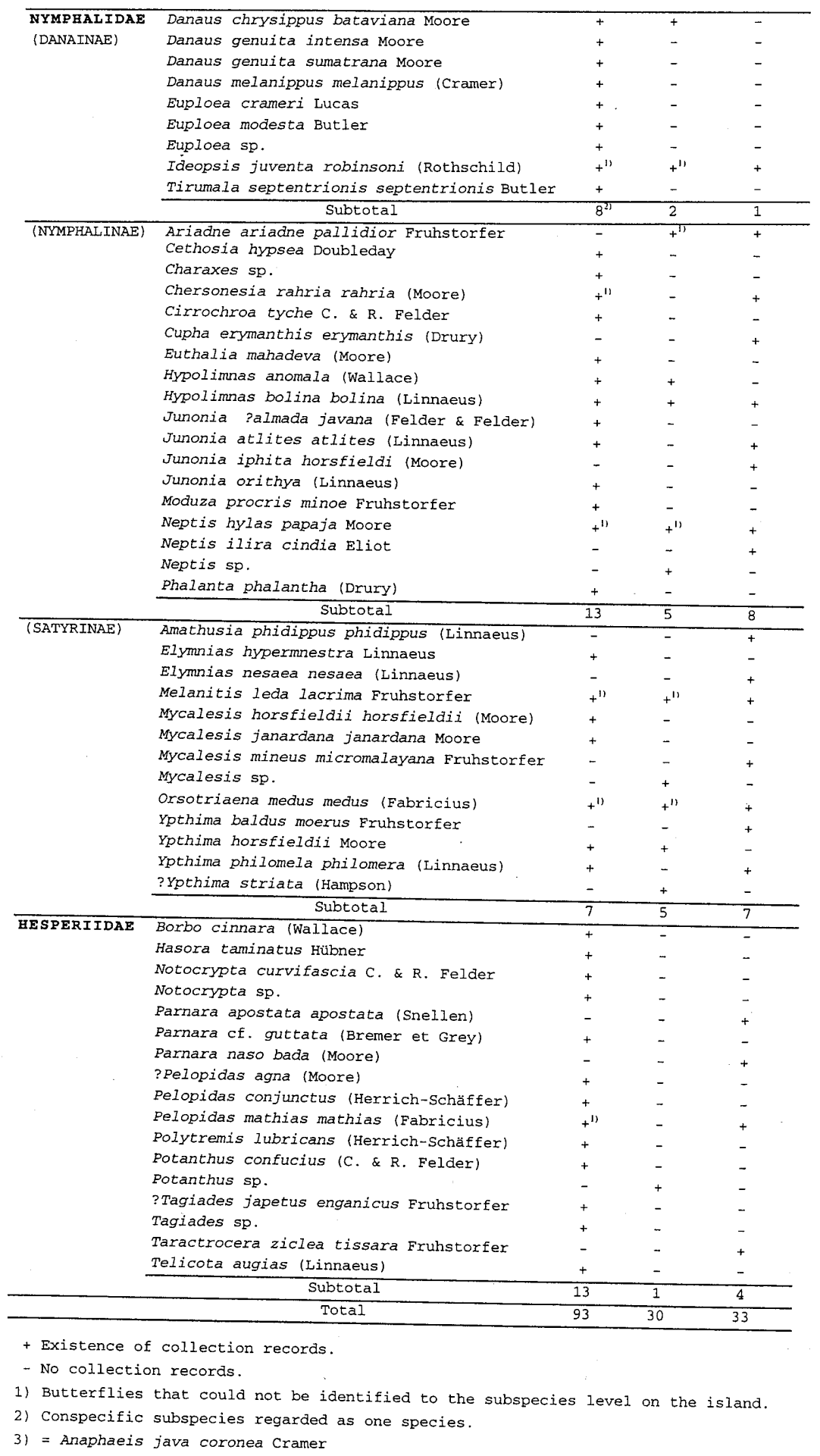


a distributional range including Java, but not Sumatra, and the Sumatran category includes species with Sumatra, but not Java in the distributional range. For species in the third category, the range covers a wide area, including both Java and Sumatra.

Six subspecies out of the 28 were referable to the Javanese and 9 to the Sumatran category, whilst the remaining 13 were put into the Wide distribution category and were not available for analysis of the place of derivation (Table 1). The Sumatran category naturally includes more subspecies than the Javanese category, since Sebesi and Sebuku are closer to Sumatra than to Java (Fig. 1). However, the ratio of subspecies that were common to both Sebesi-Sebuku and the Krakataus was distinctly higher for species in the Javanese category $(50.0 \%$ ) than for those in the Sumatran category (22.2\%) (Table 3).

Conspecific Javanese and Sumatran subspecies have been recorded to coexist on the Krakataus in Pachliopta aristrochiae (Papilionidae) and Danaus genuita (Nymphalidae: Danainae) (Table 2). On Sebesi-Sebuku, however, there was no example of the coexistence of conspecific Javanese and Sumatran subspecies. In addition, in the case of Appias lyncida (Pieridae), the Javanese subspecies, A. l. lyncida was found on the Krakataus (Table 2), whilst the Sumatran subspecies, A. l. hippo was on Sebuku (Table $1)$.

Table. 3. Comparison between subspecies belonging to Javanese and Sumatran categories in the proportion of subspecies common to Sebesi-Sebuk and the Krakataus.

\begin{tabular}{ccc}
\hline $\begin{array}{c}\text { Distributional } \\
\text { category }\end{array}$ & $\begin{array}{c}\text { Recorded on } \\
\text { Sebesi-Sebuku }\end{array}$ & $\begin{array}{c}\text { Recorded also on } \\
\text { the Krakataus }\end{array}$ \\
\hline Javanese & 6 & $3(50.0 \%)$ \\
Sumatran & 9 & $2(22.2 \%)$ \\
\hline Total & 15 & $5(33.3 \%)$ \\
\hline
\end{tabular}

\section{Discussion}

The present data indicate that 32.7 to $40.4 \%$ of 52 butterfly species collected recently on Sebesi-Sebuku have never been recorded from the Krakataus and that there are more Javanese subspecies on Sebesi and Sebuku than Sumatran subspecies. According to Yukawa (1984), 9 of 10 butterfly species on the Krakataus consisted of Javanese subspecies and only 1 was represented by Sumatran subspecies. A similar tendency was also noted for aculeata Hymenoptera (Sk. Yamane, 1983), in which 4 species were considered to be derived from Java and 1 from Sumatra. In termites, 2 species of Javanese origin were recognized, and 1 of Sumatran origin (Sk. Yamane et al., 1992). In addition, Toxopeus (1950) found that the butterfly and moth fauna of the Lampung district of southern Sumatra, including Sebuku and Sebesi, contains Javanese species as well as true Sumatran elements.

The aforementioned evidence suggests that there have been more frequent movements of butterfly species from Java to the Krakataus and Sebesi-Sebuku, and then to southern 
Sumatra rather than in the opposite direction. However, as Dammerman (1948) warned, we must keep in mind that some, probably not many, Javanese representatives on SebesiSebuku and on the Krakataus possibly derived from southern Sumatra, since we cannot distinguish between Javanese representatives from Java and Sumatra. The existence of conspecific Javanese and Sumatran subspecies on the Krakataus may suggest the possibility of derivation from both Java and Sumatra.

\section{Acknowledgements}

We wish to express our hearty thanks to Prof. I. W. B. Thornton, La Trobe University, Australia, who critically read through the draft. Our thanks are also extended to the Japanese Society for the Promotion of Sciences (JSPS) for financial support and to the Indonesian Institute of Sciences (LIPI) for allowing us to survey Sebesi and Sebuku Islands. The map and tables in this paper were prepared by Miss N. Uechi, Entomological Laboratory, Kyushu University, to whom we are deeply indebted. We thank Prof. A. Nakanishi, Museum of Nature and Human Activity, Hyogo, for sending us some of literature.

\section{References}

Bush, M. B., 1986. The butterflies of Krakatoa. Ent. Month. Mag., 122: 51-58.

Bush, M. B., D. J. B. Bush \& R. D. Evans, 1990. Butterflies of Krakatau and Sebesi: New records and habitat relations. pp. 35-41, In Whittaker et al. (eds.) Krakatau Research Project 1989 Expedition Report. 62pp., School of Geography, University of Oxford, Oxford.

Bush, M. B. \& R. J. Whittaker, 1991. Krakatau: Colonization patterns and hierarchies. J. Biogeogr., 18: 341-356.

Corbet, A. S. \& H. M. Pendlebury, 1978. The Butterflies of the Malay Peninsula [3rd edn, revised by J. N. Eliot]. xiv+578pp., 35pls., Malayan Nature Society, Kuala Lumpur, Malaysia.

Dammerman, K. W., 1922. The fauna of Krakatau, Verlaten Island and Sebesy. Treubia, 3: $61-112$.

Dammerman, K. W., 1948. The fauna of Krakatau 1883-1933. Verhandl. Koninkl. Ned. Akad. Wetenschap. Afdel. Natuurk., (2), 44: 1-594.

Docters van Leeuwen, W. M., 1923. The vegetation of the island of Sebesy, situated in the Sunda-Strait, near the islands of the Krakatau group, in the year 1921. Ann. Jard. Bot. Buitenzorg, 32: 135-192.

Evans, W. H., 1949. A Catalogue of the Hesperiidae from Europe, Asia and Australia in the British Museum (Natural History). 502pp., 53pls., The British Museum (Natural History), London.

New, T. R., M. B. Bush, I. W. B. Thornton \& H. K. Sudarman, 1988. The butterfly fauna of the Krakatau Islands after a century of recolonization. Philosoph. Trans. Roy. Soc. London B, 322: 445-457.

New, T. R. \& I. W. B. Thornton, 1992. The butterflies of Anak Krakatau, Indonesia: Faunal development in early succession. J. Lep. Soc., 46: 83-96. 
Otsuka, K. (ed.), 1988/1991. Butterflies of Borneo. Vols. I-II. Vol.I (Papilionidae, Pieridae, Danaidae, Satyridae), 1988, xx+61pp.+80pls.; Vol.II (No.1 Lycaenidae, x+139pp., 72pls.; No.2 Hesperiidae \& Addendum of Vol.I, xiii+89pp., 48pls.). Tobishima Co. Ltd., Tokyo.

Thornton, I. W. B., 1996a. Krakatau, The Destruction and Reassembly of an Island Ecosystem. 345pp. Harvard Univ. Press, Cambridge, Massachusetts, and London.

Thornton, I. W. B., 1996b. The origins and development of island biotas as illustrated by Krakatau. pp. 67-90, In Keast, A. \& S. G. Miller (eds.). The Origin and Evolution of Pacific Island Biotas. New Guinea to Eastern Polynesia: Patterns and Processes. SPB Academic Publishing, The Netherlands.

Toxopeus, L. J., 1950. Over de pioneer-fauna van Anak Krakatau, met enige beschouwingen over het onstaat van de Krakatau-fauna. Chronica Nat., 106: 27-34.

Tsukada, E. (ed.), 1980-1991. Butterflies of South East Asian Islands. Vol.I. Papilionidae, 1980, 459pp., 166pls. Plapac Co. Ltd., Tokyo; Vol.II. Pieridae \& Danaidae, 1981, 628pp., 162pls. Plapac Co. Ltd., Tokyo; Vol.III. Satyridae \& Amathusiidae, 1982, 500pp., 152pls. Plapac Co. Ltd., Tokyo; Vol.IV. Libytheidae \& Nymphalidae 1, 558pp., 157pls. Azumino-chorui-kenkyusho, Matsumoto; Vol.V. Nymphalidae 2, 1991, 576pp., 238pls. Azumino-chorui-kenkyusho, Matsumoto.

Yamane, Sk., 1983. The aculeate fauna of the Krakatau Islands (Insecta, Hymenoptera). Rep. Fac. Sci., Kagoshima Univ. (Earth Sci. \& Biol.), (16): 75-107.

Yamane, Sk., T. Abe, \& J. Yukawa, 1992. Recolonization of the Krakataus by Hymenoptera and Isoptera (Insecta). GeoJournal, 28: 213-218.

Yata, O., 1995. A revision of the Old World species of the genus Eurema Hübner (Lepidoptera, Pieridae). V. Description of the hecabe group (part). Bull. Kitakyushu Mus. Nat. Hist., (14): 1-54, pls. 1-35.

Yukawa, J., 1984. Geographical ecology of the butterfly fauna of the Krakatau Islands, Indonesia. Tyô to $G a, 35:$ 47-74. 